Aspirasi: Jurnal Masalah-Masalah Sosial | Volume 9, No. 1 Juni 2018

ISSN: 2086-6305 (print) ISSN: 2614-5863 (electronic)

DOI: https://doi.org/10.22212/aspirasi.v7il.1084

link online: http://jurnal.dpr.go.id/index.php/aspirasi/index

\title{
STUNTING : STUDI KONSTRUKSI SOSIAL MASYARAKAT PERDESAAN DAN PERKOTAAN TERKAIT GIZI DAN POLA PENGASUHAN BALITA DI KABUPATEN JEMBER
}

\author{
Stunting: Study of Social Constructions \\ in Rural and Urban Communities Related To Infant's Nutrition \\ and Nurture in Jember Municipality
}

\section{Weny Lestari, Lusi Kristiana, dan Astridya Paramita}

weny716@gmail.com

Puslitbang Humaniora dan Manajemen Kesehatan Badan Litbangkes Kemenkes RI

Jl.Indrapura 17 Surabaya

Naskah Diterima: 14 Juni 2017 | Naskah direvisi: 15 Maret 2018 | Naskah diterbitkan: 30 Juni 2018

\begin{abstract}
Indonesia rank 5th in the world on stunting case. Five million children under the age of five (38.6\% of 12 million) in Indonesia were stunting. The aims of this study were to describe the social construction of rural-urban community about the meaning of children's health and illness, and the pattern of nurturing which was related to stunting. The study used qualitative method. Data collected through depth interview and participant observation. The study was conducted in rural and-urban communities with the highest stunting cases in Jember (Kalisat and Jelbuk). The seven months study was conducted from June to December 2013. The study showed that stunting were related to social construction. Different social construction in rural-urban constructed the meaning of healthy or illness and nurturing stunting's children was affected by mother's education, early-age of marriage, after marriage's residence, responsibilities of nurturing, and valuable concept in community that causes the lack of knowledge about nutrition. The study concluded that stunting was not the single cause of health's problems, but it strongly related to social construction within the communities. Causes lied in the distinction of social construction, patterns of communication and interpretation between health providers and community, so there was no meeting point for the success of national nutrition intervention program for children under the age of five.
\end{abstract}

Keywords: social construction, rural-urban, nurturing, stunting

\begin{abstract}
Abstrak: Kejadian anak di bawah lima tahun (balita) pendek (stunting) di Indonesia masih menempati urutan ke-5 di dunia. Terdapat lima juta (38,6\% dari 12 juta) balita di Indonesia yang memiliki tinggi badan dengan kategori pendek. Penelitian ini bertujuan untuk menggambarkan konstruksi sosial masyarakat perdesaan dan perkotaan terkait pemaknaan sehat dan sakit pada balita, dan pola pengasuhan anak terkait dengan stunting. Metode penelitian adalah kualitatif. Pengumpulan data dilakukan dengan cara wawancara mendalam dan observasi partisipasi. Penelitian dilakukan di wilayah perkotaan (Kecamatan Kalisat) dan perdesaan (Kecamatan Jelbuk) dengan kasus stunting tertinggi di Kabupaten Jember. Waktu penelitian adalah 7 bulan (Juni-Desember 2013). Hasil penelitian menunjukkan bahwa masalah stunting terkait erat dengan konstruksi sosial masyarakat. Terdapat perbedaan konstruksi sosial yang membentuk pemahaman sehat/sakit dan pola asuh balita stunting di perdesaan dan perkotaan di Jember. Konstruksi sosial tersebut dipengaruhi oleh pendidikan ibu, usia perkawinan dini, tempat tinggal setelah menikah,
\end{abstract}


tanggung jawab pengasuhan balita, dan prioritas ekonomi pada masyarakat yang menyebabkan minimnya pengetahuan masyarakat tentang gizi. Hasil penelitian menyimpulkan bahwa kejadian stunting bukan merupakan akibat tunggal masalah kesehatan balita, namun terkait erat dengan konstruksi sosial masyarakat. Penyebabnya terletak pada perbedaan konstruksi sosial yang dibangun, pola komunikasi dan pemaknaan antara tenaga kesehatan dengan masyarakat, sehingga tidak ada titik temu untuk keberhasilan program peningkatan gizi balita.

Kata Kunci: konstruksi sosial, perdesaan-perkotaan, pola pengasuhan, balita pendek (stunting)

\section{Pendahuluan}

Kejadian balita pendek (stunting) di Indonesia menempati urutan ke-5 dunia. Sekitar 5 juta dari 12 juta balita $(38,6 \%)$ di Indonesia memiliki tinggi badan di bawah rata-rata tinggi badan balita di dunia. Data Riset Kesehatan Dasar (Riskesdas) tahun 2013 memperlihatkan bahwa status gizi balita pendek di Indonesia adalah $37,2 \%$. Persentase tersebut relatif tidak menunjukkan perbaikan jika dibandingkan dengan data Riskesdas tahun 2010 (35,6\%) dan tahun 2007 (36,8\%) (Departemen Kesehatan RI, 2008; Kementerian Kesehatan RI, 2010; Kementerian Kesehatan RI, 2013).

Terjadinya stunting pada balita sering kali tidak disadari, dan setelah dua tahun baru terlihat ternyata balita tersebut pendek. Masalah gizi yang kronis pada balita disebabkan oleh asupan gizi yang kurang dalam waktu yang cukup lama akibat orang tua/keluarga tidak tahu atau belum sadar untuk memberikan makanan yang sesuai dengan kebutuhan gizi anaknya. Data Riskesdas tahun 2010 menunjukkan bahwa ada $21,5 \%$ balita usia 2 - 4 tahun yang mengonsumsi energi di bawah kebutuhan minimal, dan $16 \%$ yang mengonsumsi protein di bawah kebutuhan minimal (Kementerian Kesehatan RI, 2010). Bila hal ini berlangsung dalam waktu lama, maka akan mengganggu pertumbuhan berat dan tinggi badan balita.

Pada ibu hamil juga terdapat 44,4\% yang mengonsumsi energi di bawah kebutuhan minimal dan $49,5 \%$ wanita hamil yang mengonsumsi protein di bawah kebutuhan minimal yang berdampak pada terhambatnya pertumbuhan janin yang dikandungnya (Kementerian Kesehatan RI, 2010).
Berdasarkan survei Dinas Kesehatan Provinsi Jawa Timur, 42\% anak di Jawa Timur bisa mengalami pendek. Dinas Kesehatan Provinsi Jawa Timur telah melakukan penelitian dengan metode sampling terhadap balita berusia 0 - 5 tahun sebanyak 24.000 balita di Jawa Timur. Hasilnya menyatakan bahwa $12 \%$ Balita berpotensi mengalami kecenderungan sangat pendek dan 30\% pendek (Jawa Pos, 20 Januari 2012). Berdasarkan Profil Kesehatan Provinsi Jawa Timur tahun 2011, kabupaten dengan status balita gizi kurang dan status gizi buruk terbanyak berada di Kabupaten Jember, sebanyak $20.658 \quad(13,79 \%)$ dan 4.608 (3,08\%) (Dinas Kesehatan Provinsi Jawa Timur, 2011). Indeks Pembangunan Kesehatan Masyarakat dari Riset Kesehatan Dasar 2007 menunjukkan bahwa status gizi balita pendek dan sangat pendek di Kabupaten Jember berada di peringkat ke-5 di Jawa Timur (42,79\%) (Departemen Kesehatan RI, 2008).

Program pemerintah dalam penanggulangan masalah gizi pada balita sudah cukup banyak dan terstruktur. Namun, pada kenyataannya, kasus kejadian balita stunting masih banyak dijumpai pada masyarakat dengan karakteristik sosial budaya ekonomi di level manapun. Bagaimana stunting dan masalah gizi pada balita bisa terjadi? Hal ini bisa dikaitkan dengan bagaimana masyarakat itu memberi pemaknaan tentang sehat/sakit pada balita, gizi dan pola asuh balita. Pada komunitas budaya, makna terkonstruksi secara sosial. Pengetahuan dibangun dalam komunitas dan dimaknai oleh individu sehingga membentuk pemahaman yang diyakini sebagai nilai yang ada dalam 
sebuah komunitas. Hal tersebut bisa terjadi beda makna antara komunitas satu dengan yang lain. Ketika balita pendek (stunting) oleh masyarakat dipandang bukan sebagai masalah dalam perkembangan kesehatan balita, maka prioritas dalam pola pengasuhan bisa menjadi berbeda dalam pemenuhan kebutuhan gizi balita.

Tujuan dari tulisan ini adalah untuk memberi gambaran tentang konstruksi sosial masyarakat yang membentuk pemahaman ibu tentang (1) balita sehat/sakit, (2) status gizi balita pendek (stunting), dan (3) pola asuh pada balita pendek (stunting).

Manfaat dari tulisan ini dengan diperolehnya gambaran konstruksi sosial masyarakat terkait gizi dan pola asuh balita pendek (stunting), maka informasi yang disampaikan dalam tulisan ini diharapkan dapat memberi masukan dalam pelaksanaan kebijakan program kesehatan. Manfaat terutama bagi Dinas Kesehatan Kabupaten Jember dan Pemerintah Daerah Kabupaten Jember dalam mengambil keputusan terkait perbaikan kesehatan dan peningkatan gizi balita dengan mempertimbangkan sisi budaya masyarakatnya.

Penelitian ini dilakukan dengan metode pendekatan kualitatif. Pengumpulan data dilakukan dengan cara wawancara mendalam dan observasi partisipasi. Informan adalah ibu dari balita pendek dan bidan desa setempat. Data ditentukan berdasarkan kecukupan informasi tentang pemaknaan sehat/sakit dan pola pengasuhan pada balita. Kecukupan data adalah saat data dianggap sudah jenuh ketika terjadi keberulangan informasi yang didapat dari metode triangulasi data.

Penelitian dilakukan di 2 (dua) wilayah di Kabupaten Jember dengan kasus balita pendek (stunting) paling tinggi, dan menggambarkan karakteristik masyarakat yang khas terkait perdesaan (Desa Sucopangepok, Kecamatan Jelbuk) dan perkotaan (Desa Kalisat, Kecamatan Kalisat). Waktu penelitian adalah 7 (tujuh) bulan (Juni - Desember 2013).

\section{Balita Pendek (Stunting)}

Berdasar Keputusan Menteri Kesehatan Nomor 1995/MENKES/SK/XII/2010 tanggal 30 Desember 2010 tentang Standar Antropometri Penilaian Status Gizi Anak, pengertian pendek dan sangat pendek adalah status gizi yang didasarkan pada Indeks Panjang Badan menurut Umur $(\mathrm{PB} / \mathrm{U})$ atau Tinggi Badan menurut Umur (TB/U) yang merupakan padanan istilah stunted (pendek) dan severely stunted (sangat pendek) (Kementerian Kesehatan RI, 2010). Dengan kata lain, stunting dapat diketahui bila seorang balita sudah ditimbang berat badannya dan diukur panjang atau tinggi badannya, lalu dibandingkan dengan standar, dan hasilnya berada di bawah normal. Jadi secara fisik balita akan lebih pendek dibandingkan balita seumurnya.

Klasifikasi status gizi secara umum bisa dilihat pada Tabel 1. Sementara untuk perbandingan standar status gizi balita antara yang memiliki panjang badan/tinggi badan normal dengan yang pendek bisa dilihat pada Tabel 2 .

Dalam Wahdah (2012) dinyatakan bahwa Stunting atau tubuh yang pendek, merupakan

Tabel 1. Tabel Status Gizi

\begin{tabular}{|c|c|c|}
\hline Indeks & Status Gizi & Ambang Batas *) \\
\hline \multirow{4}{*}{ Berat badan menurut umur $(\mathrm{BB} / \mathrm{U})$} & Gizi Lebih & $>+2 \mathrm{SD}$ \\
\hline & Gizi Baik & $\geq-2$ SD sampai +2 SD \\
\hline & Gizi Kurang & $<-2$ SD sampai $\geq-3 \mathrm{SD}$ \\
\hline & Gizi Buruk & $<-3 \mathrm{SD}$ \\
\hline \multirow{3}{*}{ Tinggi badan menurut umur (TB/U) } & Normal & $\geq 2 \mathrm{SD}$ \\
\hline & Pendek & $<-2$ SD sampai dengan $\geq-3 \mathrm{SD}$ \\
\hline & Sangat Pendek & $<-3 \mathrm{SD}$ \\
\hline $\begin{array}{l}\text { Berat badan menurut tinggi badan } \\
\text { (BB/TB) }\end{array}$ & $\begin{array}{l}\text { Gemuk } \\
\text { Normal } \\
\text { Kurus } \\
\text { Kurus Sekali }\end{array}$ & $\begin{array}{l}>+2 \text { SD } \\
\geq-2 \text { SD sampai }+2 \text { SD } \\
<-2 \text { SD sampai } \geq-3 \text { SD } \\
<-3 \text { SD }\end{array}$ \\
\hline
\end{tabular}

Sumber : Kementerian Kesehatan RI, 2010 
Tabel 2. Perbandingan Standar Pertumbuhan Balita Normal dan Balita Pendek

\begin{tabular}{|c|c|c|c|c|}
\hline \multirow{3}{*}{$\begin{array}{l}\text { Umur } \\
\text { (Bulan) }\end{array}$} & \multicolumn{2}{|c|}{ Normal (Median) } & \multicolumn{2}{|c|}{ Pendek (-3SD) } \\
\hline & \multicolumn{2}{|c|}{$\begin{array}{c}\text { Panjang Badan }\left(\mathrm{PB}^{*}\right) / \text { Tinggi Badan }\left(\mathrm{TB}^{* *}\right) \\
\text { (dalam satuan centimeter) }\end{array}$} & \multicolumn{2}{|c|}{$\begin{array}{c}\text { Panjang Badan (PB)/Tinggi Badan (TB) } \\
\text { (dalam satuan centimeter) }\end{array}$} \\
\hline & Laki-Laki & Perempuan & Laki-Laki & Perempuan \\
\hline 0 & 49,9 & 49,1 & 44,2 & 43,6 \\
\hline 1 & 54,7 & 53,7 & 48,9 & 47,8 \\
\hline 2 & 58,4 & 57,1 & 52,4 & 51,0 \\
\hline 3 & 61,4 & 59,8 & 55,3 & 53,5 \\
\hline 4 & 63,9 & 62,1 & 57,6 & 55,6 \\
\hline 5 & 65,9 & 64,0 & 59,6 & 57,4 \\
\hline 6 & 67,6 & 65,7 & 61,2 & 58,9 \\
\hline 7 & 69,2 & 67,3 & 62,7 & 60,3 \\
\hline 8 & 70,6 & 68,7 & 64,0 & 61,7 \\
\hline 9 & 72,0 & 70,1 & 65,2 & 62,9 \\
\hline 10 & 73,3 & 71,5 & 66,4 & 64,1 \\
\hline 11 & 74,5 & 72,8 & 67,6 & 65,2 \\
\hline 12 & 75,7 & 74,0 & 68,6 & 66,3 \\
\hline 30 & 91,9 & 90,7 & 81,7 & 80,1 \\
\hline 36 & 96,1 & 95,1 & 85,0 & 83,6 \\
\hline 42 & 99,9 & 99,0 & 88,0 & 86,3 \\
\hline 48 & 103,3 & 102,7 & 90,7 & 89,8 \\
\hline 54 & 106,7 & 106,2 & 93,4 & 92,6 \\
\hline 60 & 110,0 & 109,4 & 96,1 & 95,2 \\
\hline
\end{tabular}

*PB : Pengukuran Panjang Badan dilakukan dalam posisi anak terlentang

**TB : Pengukuran Tinggi Badan dilakukan dalam posisi anak berdiri

Sumber : Standar Antropometri Penilaian Status Gizi Anak, Kemenkes RI, 2010.

suatu retardasi pertumbuhan linier telah Perawakan pendek adalah apabila tinggi digunakan sebagai indikator secara luas badan seseorang terletak di bawah persentil untuk mengukur status gizi anak. Pendek minus 3 SD pada grafik pertumbuhan. Stunting sering dipakai sebagai terjemahan stunting menggambarkan keadaan gizi kurang yang dan terdapat suatu unsur atau elemen maupun sudah berjalan lama dan memerlukan waktu nuansa yang tidak tercakup dalam pengertian bagi anak-anak untuk berkembang serta pulih pendek. Dengan kata lain stunting tidak kembali. Anak-anak yang bertubuh pendek hanya sekadar pendek saja, tetapi terkandung pada usia dini terus menunjukkan kemampuan adanya proses perubahan patologis, jadi tidak yang lebih buruk dalam fungsi kognitif yang semata-mata pendek atau shortness saja. beragam dan prestasi sekolah yang lebih buruk Stunting merupakan gambaran keadaan masa dibandingkan dengan anak-anak yang bertubuh lalu (kronis), karena hambatan atau gangguan pertumbuhan tinggi badan atau pertumbuhan linier memerlukan waktu lama, dalam hitungan bulan atau bahkan tahun. Jika di suatu masyarakat banyak anak dengan tinggi badan menurut umur lebih rendah dari baku rujukan, maka dapat memberikan indikasi bahwa di masyarakat yang bersangkutan terdapat masalah pembangunan secara umum seperti layanan sosial air bersih, pendidikan, kesehatan dan lain-lain. Perawakan pendek sering kali dikaitkan dengan hambatan pertumbuhan (growth retardation), bahkan digunakan sebagai petunjuk terhadap adanya gangguan kesehatan seseorang (Wahdah, 2012).

"normal" (Wahdah, 2012).

\section{Teori Konstruksi Sosial dalam Kesehatan Masyarakat: Dasar Pemikiran, Asumsi, dan Proposisi}

Gambaran kerangka konsep konstruksi sosial terkait pemaknaan balita pendek di masyarakat dapat dilihat pada Gambar 1.

Teori konstruksi sosial (social construction) tidak bisa terlepaskan dari bangunan teoritik yang telah dikemukakan oleh Peter L. Berger dan Thomas Luckman. Peter L. Berger merupakan sosiolog dari New School for Social Reserach, New York, Sementara Thomas Luckman adalah sosiolog dari University of Frankfurt. Teori konstruksi 


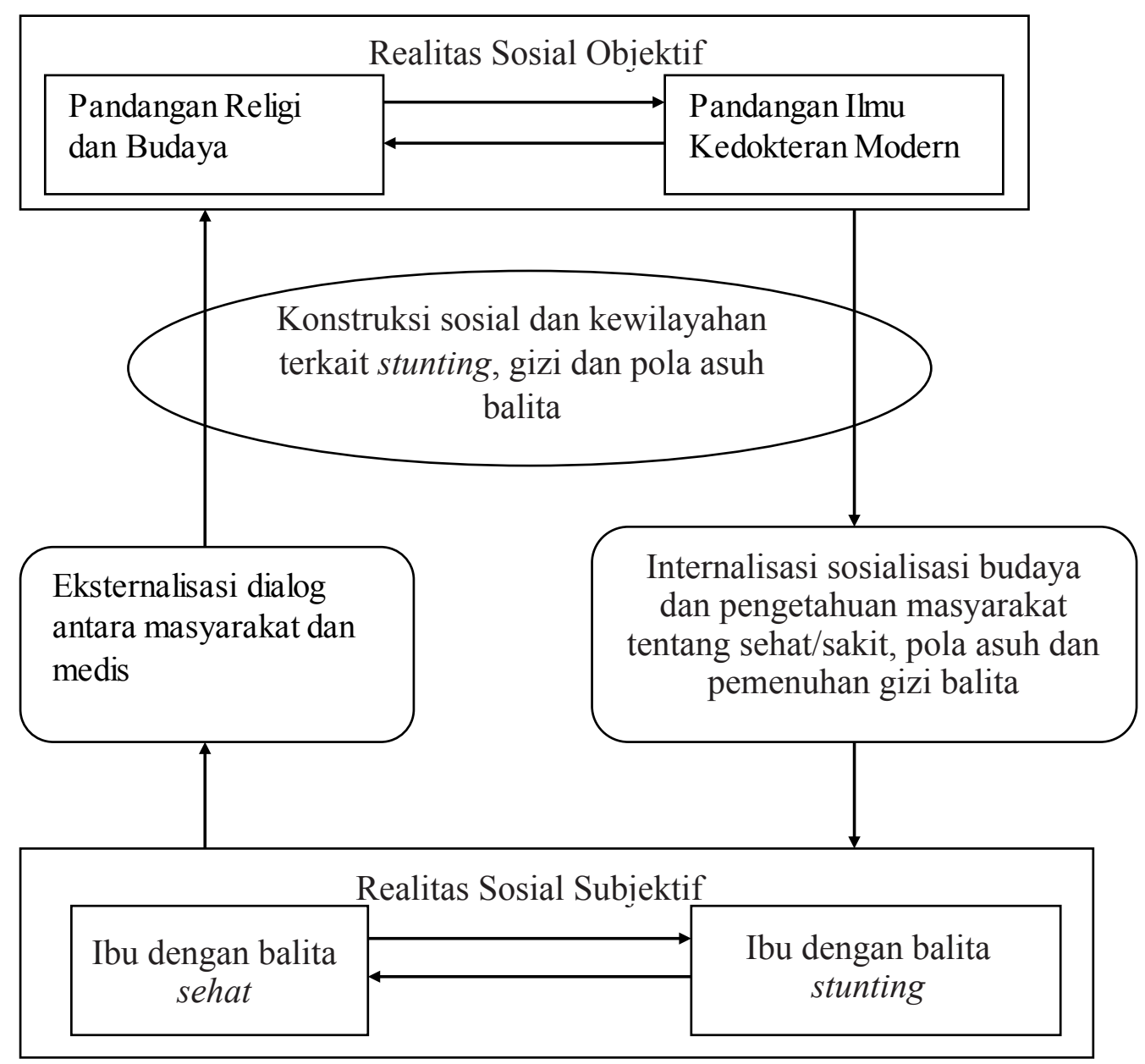

Gambar 1. Kerangka Konsep Konstruksi Sosial Balita Pendek (Stunting)

sosial, sejatinya dirumuskan kedua akademisi ini sebagai suatu kajian teoretis dan sistematis mengenai sosiologi pengetahuan. Berger dan Luckman meyakini secara substantif bahwa realitas merupakan hasil ciptaan manusia kreatif melalui kekuatan konstruksi sosial terhadap dunia sosial di sekelilingnya, "reality is socially constructed" (Berger \& Luckman, 1990).

Dasar dari teori konstruksi sosial adalah pemikiran Max Weber yang menjelaskan bahwa manusia bertindak atas dasar pemaknaannya pada kenyataan sosial di sekitarnya. Dari pemaknaan tersebut, manusia membangun rasionalitasnya. Ada empat jenis rasionalitas yang dikembangkan manusia, yaitu (1) rasionalitas nilai (wertrationalitat), (2) rasionalitas instrumental (zweckrationaltat), (3) tindakan tradisional, dan (4) tindakan afektif. Dikatakan menggunakan rasionalitas nilai, bila orang bertindak atas dasar nilai-nilai tertentu sebagai acuan dan tujuannya. Sementara itu, tindakan dengan rasionalitas instrumental apabila orang mempertimbangkan cara atau alat yang digunakan dan tujuan tindakan tersebut. Dalam konsep ini, manusia dianggap otonom sebagai pemilik dari macam-macam tujuan yang diinginkan dan kriterianya memilih tujuan-tujuan tersebut. Demikian pula, manusia juga mampu menilai alat dan kemudian memulai proses pengumpulan informasi, mencatat kemungkinan dan hambatan, serta meramalkan konsekuensi dari tindakan itu. Akhirnya, ia memilih tujuan dan alat yang mencerminkan pertimbangan efisiensi dan efektivitasnya (Berger \& Luckman, 1990). Hal itu sudah barang tentu berbeda dengan tindakan tradisional yang mengikuti pola-pola yang telah dibentuk dari masa lalu, serta tindakan afektif yang mengikuti dorongan perasaan atau emosi.

Dalam penjelasan yang demikian, seolah-olah manusia itu otonom tidak terikat 
oleh sistem nilai dan struktur sosial. Nilai dan struktur sosial berada di "luar" manusia dan tidak atau kurang berpengaruh dalam tindakan manusia. Dengan teori konstruksi sosial, Peter L. Berger dan Thomas Luckman menjelaskan bagaimana proses dialektika antara manusia dan struktur sosial yang di dalamnya terdapat nilai-nilai sosial. Dalam teorinya, ada makna-makna umum yang dimiliki bersama dan diterima tetap dilihat sebagai dasar dari organisasi sosial. Maknamakna umum ini dikenal sebagai realitas objektif. Sementara itu, ada makna yang berkembang di luar makna umum merupakan hasil manusia yang muncul dari lingkungan sosial yang diciptakannya. Lingkungan ini adalah nilai-nilai dan makna-makna yang selalu berkembang. Makna-makna ini berkembang dan diobjektivasikan ke dalam institusi-institusi sosial dan karena itu kemudian disosialisasikan kepada anggota baru masyarakat (Craib, 1986). Proses sosialisasi ini disebut sebagai subjektivasi, memasukkan nilai ke dalam diri individu dan menjadi realitas subjektif. Namun demikian, dalam kehidupan sehari-hari manusia juga berdialog dengan sesamanya dan dikenal sebagai intersubjektif. Dengan dinamikanya, makna-makna dalam diri individu ini dapat berubah dan pada gilirannya dikembalikan ke institusi sosial dalam objektivasi. Oleh karena itu, teori ini merumuskan bahwa masyarakat adalah produk manusia. Masyarakat adalah realitas objektif dan manusia adalah produk sosial. Dengan kata lain, manusia adalah produk dari masyarakat yang mereka ciptakan (Ritzer, 1988).

Pemahaman yang serupa dapat diterapkan dalam kesehatan masyarakat. Bila mencermati dalam proses kesejarahan kedokteran modern saat ini, mulanya terbentuk dari pengetahuan dan praktik-praktik penyembuhan shaman (perdukunan) pada masa prasejarah. Proses dialektika antara pembentukan pengetahuan (rasionalitas) dan praktik-praktik itu pada gilirannya berlanjut terus-menerus seiring dengan perkembangan pemikiran manusia sebagaimana dipaparkan oleh Aguste Comte, yaitu dari teologis, metafisik hingga ke positivistik. Kedokteran modern berkembang meninggalkan logika teologis menuju logika positivistik dengan pembuktian ilmiah. Konstruksi tentang apa yang sehat dan bagaimana harus hidup sehat hingga bagaimana menyehatkan kembali (healing) dari proses sakit memperoleh pembenaran dari awalnya tindakan medis individu para penyembuh di masanya (Butt, 1998).

\section{Gambaran Balita Pendek (Stunting) di Kabupaten Jember}

Banyak masalah kesehatan ibu dan anak yang terkait dengan masalah budaya dan konstruksi masyarakatnya, termasuk masalah gizi buruk dan balita pendek. Kepala Seksi Gizi Dinas Kesehatan Kabupaten Jember menyatakan bahwa pada tahun 2013, data mengenai balita pendek (stunting) di wilayah Kabupaten Jember berdasarkan urutan 2 (dua) besar per wilayah kecamatan adalah sebagai Tabel 3.

Tabel 3. Data Balita Pendek di Kabupaten Jember per Agustus 2013

\begin{tabular}{llc}
\hline No & Kecamatan & $\begin{array}{l}\text { Persentase Balita Pendek } \\
\text { dari Balita yang diperiksa } \\
(\mathbf{\%})\end{array}$ \\
\hline 1 & Kalisat & 75 \\
2 & Jelbuk & 68,75 \\
3 & Kaliwates & 38 \\
4 & Tanggul & 35 \\
5 & Sumbersari & 25 \\
\hline
\end{tabular}

Sumber: Dinas Kesehatan Kab. Jember, 2013

Data tersebut menunjukkan wilayah dengan persentase kejadian balita pendek (stunting) tertinggi yang mewakili wilayah perdesaan (Kecamatan Jelbuk) dan perkotaan (Kecamatan Kalisat).

Berdasarkan data Puskesmas Kecamatan Kalisat tahun 2013, persentase balita pendek (stunting) tertinggi (75\%) di Kecamatan Kalisat. Dari 20 balita yang diperiksa, ada 15 balita masuk dalam kategori pendek $\leq-3$ SD (lihat Tabel 2). Sementara itu, di wilayah Kecamatan Jelbuk, data Puskesmas Kecamatan Jelbuk mencatat ada 25 balita di Bawah Garis Merah (BGM) dan di antaranya ada 9 balita yang masuk dalam kategori sangat pendek $\leq-3$ SD (lihat Tabel 2) (Puskesmas Kecamatan 
Tabel 4. Status Kesehatan Balita Pendek dan Sangat Pendek di Desa Sucopangepok, Tahun 2013

\begin{tabular}{llllllllll}
\hline Nama & $\begin{array}{l}\text { Jenis } \\
\text { Kelamin }\end{array}$ & Golongan & $\begin{array}{l}\text { Umur } \\
(\text { bulan) }\end{array}$ & $\begin{array}{l}\text { BB } \\
(\mathrm{kg})\end{array}$ & $\begin{array}{l}\text { TB } \\
(\mathrm{cm})\end{array}$ & BB/TB & TB/U & Keterangan & $\begin{array}{l}\text { Keluhan } \\
\text { Penyakit }\end{array}$ \\
\hline $\begin{array}{l}\text { Balita } \\
\text { W }\end{array}$ & Laki-laki & Gakin* & 31 & 8,9 & 82 & Normal & $\begin{array}{l}\text { Sangat } \\
\text { Pendek }\end{array}$ & BGM*** & $\begin{array}{l}\text { Batuk, Pilek, } \\
\text { Sesak }\end{array}$ \\
\hline $\begin{array}{l}\text { Balita } \\
\text { R }\end{array}$ & Laki-laki & $\begin{array}{l}\text { Non } \\
\text { Gakin** }\end{array}$ & 31 & 9 & 81 & Normal & $\begin{array}{l}\text { Sangat } \\
\text { Pendek }\end{array}$ & BGM & $\begin{array}{l}\text { Mencret, Batuk, } \\
\text { Pilek }\end{array}$ \\
\hline $\begin{array}{l}\text { Balita } \\
\text { K }\end{array}$ & Laki-laki & NonGakin & 17 & 8 & 69 & Normal & Pendek & KEP Ringan & $\begin{array}{l}\text { Batuk, Pilek, } \\
\text { Mencret }\end{array}$ \\
\hline $\begin{array}{l}\text { Balita } \\
\text { D }\end{array}$ & Laki-laki & NonGakin & 25 & 10 & 81 & Normal & Pendek & $\begin{array}{l}\text { Dropout } \\
\text { (BB Naik) }\end{array}$ & Batuk, Pilek \\
\hline
\end{tabular}

Keterangan:

* Gakin: keluarga miskin

** Non Gakin: bukan keluarga miskin

*** BGM: Bawah Garis Merah

Sumber: Laporan Penimbangan Tingkat Posyandu Desa Sucopangepok Kecamatan Jelbuk Jember Per September 2013

Kalisat, 2013; Puskesmas Kecamatan Jelbuk, BGM.

2013).

\section{Balita Pendek di Perdesaan (Desa} Sucopangepok, Kecamatan Jelbuk)

Desa Sucopangepok terdiri dari 10 dusun, dusun yang dijadikan tempat penelitian adalah Dusun Krajan Timur dan Dusun Krajan Barat. Dusun Krajan Timur dan Krajan Barat adalah dusun yang saling berbatasan langsung. Dusun Krajan Timur adalah tempat di mana Balai Desa dan Polindes Sucopangepok berada. Di Dusun Krajan Timur tercatat ada 3 balita yang masuk dalam kategori pendek, dengan 2 di antaranya masuk juga dalam kategori BGM. Sementara itu, di Dusun Krajan Barat berada di sebelah barat Balai Desa Sucopangepok, di sana tercatat satu balita yang masuk dalam kategori pendek dan

\section{Balita Pendek di Perkotaan (Desa Kalisat, Kecamatan Kalisat)}

Desa Kalisat dipilih berdasarkan data Puskesmas yang merupakan desa dengan tipikal perkotaan menurut BPS dengan kasus kejadian balita pendek dan gizi kurang. Didapatkan gambaran status gizi balita seperti pada Tabel 5 .

Data responden balita pendek di perdesaan maupun perkotaan didapatkan bahwa 7 dari 8 orang responden balita pendek memiliki berat badan lahir normal $(>2.500$ gram). Hanya 1 balita yang memiliki berat badan lahir di bawah standar normal seberat 2.300 gram. Sementara itu, panjang badan lahir, 8 balita memiliki panjang badan normal $>49$

Tabel 5. Status Kesehatan Balita Pendek dan Sangat Pendek di Desa Kalisat Tahun 2013

\begin{tabular}{llllllllll}
\hline Nama & $\begin{array}{l}\text { Jenis } \\
\text { Kelamin }\end{array}$ & Golongan & $\begin{array}{l}\text { Umur } \\
\text { (bulan) }\end{array}$ & $\begin{array}{l}\text { BB } \\
(\mathrm{kg})\end{array}$ & $\begin{array}{l}\text { TB } \\
(\mathrm{cm})\end{array}$ & BB/TB & TB/U & Keterangan & $\begin{array}{l}\text { Keluhan } \\
\text { Penyakit }\end{array}$ \\
\hline $\begin{array}{l}\text { Balita } \\
\text { Ga }\end{array}$ & Laki-laki & NonGakin* & 27 & 9,3 & 81 & Normal & Pendek & BGM** & Batuk, pilek \\
\hline $\begin{array}{l}\text { Balita } \\
\text { Gi }\end{array}$ & Laki-laki & NonGakin & 27 & 9,5 & 80 & Normal & Pendek & BGM & Batuk, pilek \\
\hline $\begin{array}{l}\text { Balita } \\
\mathrm{R}\end{array}$ & Laki-laki & NonGakin & 35 & 9,6 & 80 & Kurus & Pendek & BGM & - \\
\hline $\begin{array}{l}\text { Balita } \\
\text { A }\end{array}$ & Perempuan & NonGakin & 55 & 10,3 & 85 & Normal & $\begin{array}{l}\text { Sangat } \\
\text { Pendek }\end{array}$ & BGM & - \\
\hline
\end{tabular}

Keterangan:

* Non Gakin: bukan keluarga miskin

** BGM: Bawah Garis Merah

Sumber: PSG Puskesmas Kecamatan Kalisat Agustus 2013

Weny Lestaridkk Stunting: Studi Kanstruksi Sasial Masyarakat Pedesaan dan Perkataan... 
Tabel 6. Konstruksi Sosial Masyarakat terkait Makna Sehat/Sakit, Pola Asuh dan Gizi Balita Pendek di Perdesaan dan Perkotaan Kabupaten Jember, Provinsi Jawa Timur, Tahun 2013

\begin{tabular}{ll}
\hline & \multicolumn{1}{c}{ Perdesaan } \\
\hline & Ada kepercayaan di masyarakat bahwa balita sakit \\
& sebagai hasil perbuatan orang lain (nonmedis), \\
Pemaknaan & sehingga dalam perawatan medis tidak maksimal \\
Balita Sehat/ & karena ibu menganggap pengobatan medis sia-sia. \\
Sakit & - Anak yang masih bisa beraktivitas dengan normal \\
& dianggap sehat meskipun pendek, kurus dan mudah \\
& terinfeksi penyakit.
\end{tabular}

Pengetahuan - Anak yang pendek asal bisa beraktivitas seperti tentang biasa dianggap sehat. Namun, pengetahuan tentang Balita balita kurang gizi diketahui dari tenaga kesehatan Pendek dan kejadian sering sakitnya anak.
- Anak sakit itu saat tidak bisa bermain dan nafsu makan menurun.

- Anak yang masih bisa beraktivitas dengan normal dianggap sehat meskipun pendek, kurus dan mudah terinfeksi penyakit.

- Anak pendek dan kurang gizi dianggap tidak terjadi pada anaknya, tapi terjadi pada anak orang lain. Karena dianggap pola pemberian makan kepada anak masih dalam taraf cukup.

- Tinggi badan anak yang kurang dianggap merupakan keturunan dari orang tua yang juga pendek. Tinggi badan pendek bukan masalah.

- Pengasuhan balita sepenuhnya dipegang oleh ibu dan keluarga luas dari pihak ibu.

- Pengetahuan pengasuhan anak didapatkan dari keluarga. Rata-rata ibu balita berpendidikan rendah (Tidak Tamat SD/Tidak Tamat SMP), hanya sedikit yang tamat SLTA.

- Usia perkawinan ibu sekitar 14-15 tahun, sehingga memiliki anak namun kurang pengetahuannya.

- Pengetahuan PHBS dalam keluarga rendah

- Anak perempuan lebih diinginkan karena dianggap anak perempuan bisa membantu tugas berat ibu di rumah dan di kebun, sedangkan anak laki-laki sepertinya hanya bertugas untuk main, dianggap nakal dan tidak bisa membantu.

- Pengasuhan anak seadanya, tidak ada upaya untuk meningkatkan kesehatan anak, karena prioritas utama adalah peningkatan ekonomi dan barangbarang berharga sebagai kepemilikan.

- Pengasuhan balita dipegang oleh ibu dan keluarga luas dari pihak bapak. Apabila sudah memasuki usia sekolah prioritas akan dimasukkan ke pesantren.

- Pengetahuan pengasuhan anak didapatkan dari keluarga, tenaga kesehatan, dan media. Pendidikan ibu bervariasi ada yang S-1, tamat SLTA, dan tamat SMP.

- Usia perkawinan ibu relatif lebih tinggi sekitar 17-25 tahun, dianggap cukup matang dalam mengasuh anak.

- Pengetahuan PHBS dalam keluarga rendah

- Anak laki-laki atau perempuan dianggap sama, namun anak laki-laki lebih diistimewakan dalam pengasuhan dan pendidikan daripada anak perempuan.

- Pengasuhan anak seadanya, tidak ada upaya untuk meningkatkan kesehatan anak, karena prioritas utama adalah peningkatan ekonomi dan barang-barang berharga sebagai kepemilikan.

- Ibu mengetahui dan menyadari bahwa anaknya masuk kategori gizi kurang dan sering sakit, namun tidak melakukan apa-apa

- Penggunaan garam krosok (tidak beryodium) dalam pengolahan masakan dalam keluarga. Anggapan garam beryodium rasa kurang asin dan minimnya penjual garam beryodium.

- Penggunaan makanan instan (mi instan, makanan ringan, ikan asin, makanan kaleng, sosis daging olahan) dalam

Gizi pemberian makan pada balita cukup tinggi.

- Ada pandangan bahwa susu formula yang harganya mahal lebih baik daripada ASI.

- Program PMT dari pemerintah, tidak digunakan untuk keperluan balita saja, namun untuk konsumsi seluruh keluarga.

- Pola pemberian makan pada anak tidak teratur, hanya berdasarkan kesukaan anak saja, dan memberi uang jajan pada balita. Pemberian makan tidak sesuai usia anak.
- Ibu mengetahui bahwa anaknya masuk kategori gizi kurang, namun menolak apabila anaknya dikatakan kurang gizi. Ibu menganggap anak balitanya sehat, karena makan anaknya dilihat cukup banyak. - Pemberian MPASI yang cukup dini $(<6$ bulan) sering menyebabkan bayi mengalami diare. Bayi menangis dianggap masih lapar. - Balita diberikan makanan ringan kemasan untuk menambah nafsu makannya. 
cm. Namun, dalam proses pertumbuhannya, 8 balita tersebut mengalami BGM dan bertubuh pendek dan sangat pendek. Sebanyak 6 balita di antaranya mempunyai komplikasi penyakit seperti ISPA dan diare. Sebanyak 7 balita dari 8 balita bukan berasal dari keluarga miskin, orang tua memiliki kondisi ekonomi yang cukup mampu, sehingga secara nyata akan tampak bahwa pemenuhan gizi balita yang seharusnya bisa terpenuhi dengan kondisi ekonomi keluarga yang cukup, tidaklah cukup membuktikan bahwa ekonomi yang baik turut berperan dalam pemenuhan gizi balita.

Tabel 6 menunjukkan pemetaan bagaimana konstruksi sosial masyarakat di 2 wilayah perdesaan dan perkotaan di Kabupaten Jember pada tahun 2013 .

\section{Konstruksi Sosial tentang Makna Sehat/Sakit}

Mengikuti cara pandang strukturalisme, kondisi sakit merupakan lawan dari sehat. Kondisi itu menggambarkan keadaan tubuh berkaitan dengan fungsinya. Kata sakit merujuk pada kondisi di mana seorang mengalami gangguan untuk melakukan fungsi sosialnya, misalnya karena badannya panas, ia tidak bisa bekerja. Sementara itu, kondisi sehat menggambarkan keadaan tubuh yang mampu menjalankan fungsi sosialnya. Kondisi sehat menggambarkan sisi positif dari keadaan tubuh (an organicbiological characteristic), sedangkan sakit menunjukkan sisi negatif. Kondisi yang digambarkan ini tidak saja berlangsung sesaat dan nampak, yaitu ada tidaknya kondisi sehat (health in vacuum), kesiapan untuk hidup sehat (reserve of health), dan keseimbangan (health as an equalibirium). Pandangan ini juga menunjukkan bahwa kondisi sehat dan sakit ini sebagai prasyarat untuk pencapaian status sosial ekonomi, atau sebagai kapasitas untuk menampilkan tugas sosial dan peran secara layak. Ringkasnya, definisi sehat dan sakit ini ditekankan pada kelangsungan fungsi individual dalam peran sosial berbeda yang dimilikinya. Fungsi sosialnya dipandang sebagai keseimbangan personal dan keberhasilan dalam memuaskan kebutuhan diri dan orang lain serta mengurangi tekanan (Noack, 1987).

Di dalam kondisi sakit, secara teoretis, ada dua perilaku pada si sakit, yaitu perilaku sakit dan perilaku sehat. Kedua perilaku itu bergerak secara hampir bersamaan dan berurutan. Pada perilaku sakit, si sakit menanggapi gejala dan melakukan evaluasi. Individu yang sakit merasa kurang nyaman atau tanda lain karena fungsi tubuh kurang baik. Hal itu ditandai dengan perasaan atau keadaan individu yang tidak dapat mengerjakan sebagian atau keseluruhan peran normalnya, dan memberikan tuntutan tambahan tingkah laku peran individu lain di sekitarnya, sementara itu perilaku sehat terjadi tatkala si sakit mencari kesembuhan dan mengembalikan fungsi sosialnya. Kedua perilaku itu disebut oleh Suchman (1965) (dalam Foster \& Anderson, 1986), sebagai pengalaman sakit (illness experience). Ada dalam 5 (lima) tahap, yaitu (1) pengalaman gejala (keputusan ada yang tidak beres), (2) asumsi sakit (keputusan seseorang merasa sakit dan membutuhkan perawatan profesional), (3) kontak perawatan medis (keputusan mencari perawatan medis profesional), (4) peran ketergantungan (keputusan mengalihkan pengawasan kepada dokter dan menerima serta mengikuti pengobatan yang diterapkan), dan (5) kesembuhan atau rehabilitas (keputusan mengakhiri peranan penderita).

Hal itu berbeda dengan Andrew Twaddle (1969) sebagaimana dikutip oleh Cockerham (Cockerham, 1978) hanya membatasi pada (1) perubahan perasaan (menjadi tidak nyaman), (2) tidak mampu menampilkan peran normalnya, dan (3) gejala atau perubahan dalam bentuk biologis dari organisme yang dipandang penting karena berimplikasi pada tindakannya. Selanjutnya, Suchman (1965) lebih menggambarkan kedua perilaku (perilaku sakit dan perilaku sehat) sebagai pengalaman sakit itu dalam rangkaian Tabel 6.

Dalam pemahaman konstruksi sosial, Tabel 6 ini menggambarkan dengan baik bagaimana 
proses dialetik antara realitas objektif dan subjektif, antara asumsi dan pengetahuan yang diperoleh dari dunia medis dan abstraksi atas pengalaman yang pernah dijalani seorang individu. Dalam dunia medis, asumsi dan gejala tentang sehat dan sakit telah terinci dengan detil dalam buku-buku kedokteran. Sementara itu, melalui pengalaman kesehariannya, individu mengalami proses-proses sakit yang dimulai dari ketidakberfungsian diri dalam dunia sosialnya. Pada Tabel 6, pada gilirannya orang menyadari sakit tidak ditentukan oleh buku kedokteran yang disampaikan oleh tenaga medis, tetapi kesadarannya tentang sakit yang dialaminya.

Dalam konteks pemahaman balita sakit yang dipahami oleh ibu di perdesaan Jember, memunculkan konstruksi sosial sendiri di luar konstruksi yang dibentuk oleh medis, bahwa balita sakit bisa dipahami oleh karena sebab gangguan dari luar secara supranatural, sehingga dalam proses penyembuhannya kurang melibatkan pengobatan dari medis. Sementara itu, di wilayah perkotaan Jember, balita sakit dipahami seperti dalam konteks fungsi tubuh saja, saat anak tidak beraktivitas seperti biasa, menurun nafsu makannya, rewel dan meminta digendong terus, serta tidak mau bermain sendiri.

Konteks balita sehat baik di perdesaan maupun di perkotaan juga dikonstruksi terkait dengan fungsi tubuh anak, anak sehat adalah yang bisa beraktivitas normal sehari-hari, mereka bisa bermain dengan teman atau saudara mereka yang lain tanpa keluhan.

\section{Konstruksi Sosial tentang Balita Pendek (Stunting)}

Teori konstruksi sosial, Peter L. Berger dan Thomas Luckman menjelaskan bagaimana proses dialektika antara manusia dan struktur sosial yang di dalamnya terdapat nilai-nilai sosial. Dalam teorinya, ada makna-makna umum yang dimiliki bersama dan diterima tetap dilihat sebagai dasar dari organisasi sosial. Makna-makna umum ini dikenal sebagai realitas objektif (Peter dan
Luckman, 1990). Sementara itu, ada makna yang berkembang di luar makna umum merupakan hasil manusia yang muncul dari lingkungan sosial yang diciptakannya. Lingkungan ini adalah nilai-nilai dan maknamakna yang selalu berkembang. Maknamakna ini berkembang dan diobjektivasikan ke dalam institusi-institusi sosial dan karena itu kemudian disosialisasikan kepada anggota baru masyarakat (Craib, 1986). Proses sosialisasi inilah yang disebut sebagai subjektivasi, memasukkan nilai ke dalam diri individu dan menjadi realitas subjektif. Namun demikian, dalam kehidupan seharihari manusia juga berdialog dengan sesamanya dan dikenal sebagai intersubjektif. Dengan dinamikanya, makna-makna dalam diri individu ini dapat berubah, dan pada gilirannya dikembalikan ke institusi sosial dalam objektivasi. Oleh karena itu, teori ini merumuskan bahwa masyarakat adalah produk manusia, masyarakat adalah realitas objektif dan manusia adalah produk sosial. Dengan kata lain, manusia adalah produk dari masyarakat yang mereka ciptakan (Ritzer, 1988).

Berdasarkan teori konstruksi sosial tersebut, maka fenomena balita pendek (stunting) adalah fenomena yang diproduksi oleh provider kesehatan atas kenyataan yang ada di masyarakat Jember khususnya di Kecamatan Kalisat dan Jelbuk, karena data balita pendek dan gizi bermasalah di dua kecamatan tersebut menempati urutan pertama dan kedua di Kabupaten Jember. Stunting menurut standar kesehatan pertumbuhan balita adalah balita yang memiliki tinggi badan yang tidak sesuai standar normal berdasarkan usia balita (lihat Tabel 2), dan dianggap berpengaruh terhadap tumbuh kembang anak baik secara fisik maupun kecerdasan anak (Kemenkes, 2010). Sementara itu, balita pendek yang dipahami oleh masyarakat Jember di perdesaan dan perkotaan adalah merupakan hal yang wajar, tidak terkait dengan masalah kesehatan anak sepanjang anak masih beraktivitas/bermain dan masih memiliki nafsu makan (lihat tabel 
6). Pendek dianggap sebagai faktor keturunan dari orang tua yang bertubuh pendek.

Balita pendek (stunting) yang terjadi di wilayah perdesaan dan perkotaan Jember terjadi setelah bayi lahir dalam masa pertumbuhannya. Sekitar 7 dari 8 bayi lahir dengan berat dan tinggi badan yang normal. Namun dalam pertumbuhannya, 8 balita tersebut mengalami stunting. Balita di wilayah Sucopangepok maupun Kalisat yang masuk dalam kategori pendek (stunting) dan gizi kurang, pada awalnya semua lahir normal dengan berat badan lahir antara 2.500 gram sampai dengan 3.800 gram, hanya 1 yang Berat Badan Lahir Rendah (BBLR) yaitu 2.300 gram. Namun, dalam pertumbuhannya, para balita tersebut mengalami kekurangan gizi. Hal ini terlihat pada pencatatan status gizi yang dilakukan oleh Posyandu. Setiap bulannya, tidak ada kenaikan berat badan dan/ atau tidak ada penurunan berat badan yang disertai dengan gejala terinfeksi penyakit seperti diare dan Infeksi Saluran Pernafasan Akut (ISPA).

Beberapa penelitian terdahulu menemukan keterkaitan antara pertumbuhan tinggi badan dan perubahan perkembangan dalam usia 3 tahun pertama. Menurut penelitian Henningham dan Mc.Gregor (2009) di Guatemala dalam Wahdah (2012) dinyatakan bahwa perubahan tinggi badan pada usia 6 - 24 bulan disertai dengan perubahan perkembangan. Di Jamaika, anak-anak berusia 6-24 bulan yang mengalami stunting, dilihat perubahan tinggi badannya dan perubahan pada kemampuan intelektualnya selama 24 bulan. Hal tersebut menunjukkan bahwa perubahan tinggi badan pada tahun pertama dapat meramalkan perubahan intelektual pada tahun kedua, kendati sudah dilakukan kontrol terhadap perubahan tinggi badan dalam tahun kedua. Stunting yang terjadi dalam usia 36 bulan pertama biasanya disertai dengan efek jangka panjang (Wahdah, 2012).

Temuan kasus stunting di Jember ini sejalan dengan temuan pada penelitian
Mahirawati et al (2007), terkait konsumsi energi dan protein pada anak usia 7-23 bulan, dinyatakan bahwa semakin bertambah umur anak, angka rerata dan tingkat konsumsi energi dan protein semakin rendah baik di perkotaan maupun di perdesaan. Dengan tidak adanya perbedaan antara rendahnya konsumsi energi dan protein di perdesaan maupun perkotaan, maka bisa dipastikan ada konstruksi sosial di balik kejadian balita pendek (stunting) (Mahirawati, 2007). Berbeda dengan yang diungkapkan oleh Sudiman dan Menon et al bahwa balita stunting disebabkan oleh kondisi sosial ekonomi keluarga, dan balita stunting banyak terjadi pada keluarga dengan tingkat sosial ekonomi rendah atau miskin (Sudiman, 2008; Menon, Ruel, Morris, 2000), maka kasus balita pendek (stunting) di Jember tidaklah demikian. Keluarga dengan sosial ekonomi tinggi maupun rendah, di perdesaan maupun perkotaan sama-sama ditemukan kejadian balita pendek (stunting).

Penurunan gizi pada balita di Jember sebagian besar terjadi setelah bayi berusia 4 sampai dengan 6 bulan, yaitu ketika bayi sudah dikenalkan pada makanan pendamping ASI. Penurunan signifikan terjadi pada berat badan bayi sehingga bayi dan balita masuk dalam BGM. Hal ini sejalan dengan yang diungkap dalam pertemuan Bappenas bahwa periode emas untuk menghindari balita pendek (stunting) dan gizi bermasalah adalah 1.000 hari, pada saat kehamilan ibu dan 2 tahun setelah bayi lahir (Hadiat, 2013).

\section{Konstruksi Sosial tentang Pola Asuh dan Pemenuhan Gizi Anak}

Dalam kajian antropologi, setiap masyarakat akan mengembangkan pola perawatan dan pengasuhan anak dari sejak dalam kandungan. Hal itu merupakan bagian dari tahapan manusia dan oleh budaya kemudian dikelola dalam bentuk ritus. Oleh Arnold van Gennep dalam Koentjaraningrat, ritus itu disebut dengan rites of passage (Koentjaraningrat, 1979). Tidak saja dalam ritus sebagai bagian dari pemahaman sakral 
tentang setiap perjalanan manusia, tetapi dalam praktik-praktik keseharian anak diasuh dan dirawat oleh keluarganya. Secara sosiologis, tidak selalu sama siapa yang bertanggung jawab terhadap perawatan dan pengasuhan, seperti dalam masyarakat Jawa, keterlibatan anggota kerabat luas termasuk di dalamnya (Geertz, 1985; Butt, 1998).

Lebih dari itu, secara teoretis, kualitas perawatan kehamilan hingga pada masa sesudahnya sebenarnya dipengaruhi oleh nilai anak pada masyarakat tersebut. Artinya, semakin bermakna keberadaan anak bagi keluarga, maka semakin cermat dalam melakukan perawatan selama kehamilan hingga anak berusia di atas lima tahun. Perawatan anak pada masa usia di bawah lima tahun dikenal dalam antropologi sebagai pola pengasuhan anak. Dalam sejumlah penelitian di Indonesia, karena nilai anak yang positif, pola pengasuhan tidak saja dilakukan oleh ibu biologis, tetapi oleh kerabat luas, seperti di Jawa (Geertz, 1985), di Trunyan Bali (Danandjaja, 1980), dan di Jakarta (Habsjah, 1995). Kondisi serupa juga dilakukan di Inggris, yang berbeda dengan di Perancis dengan adanya tempat penitipan anak. Perubahan pengasuhan dengan menyerahkan pada pengasuh atau lembaga penitipan anak (caregiver) juga terjadi di Amerika Serikat, khususnya wilayah perkotaan (Burchinal dan Nelson, 2000), begitu pula di Nigeria (Uyanga, 1980). Perubahan pola pengasuhan ini mempengaruhi dari kualitas hidup anak, seperti perawatan dan pemberian air susu, sebagaimana pada kasus di Nigeria (Uyanga, 1980), begitu pula pada kasus keluarga miskin di Jakarta, Indonesia (Habsjah, 1995). Selain perubahan pola pengasuhan, kualitas gizi anak balita ini tidak terlepas dari sejumlah faktor sosial budaya baik dari ibu atau keluarganya, antara lain adalah pengetahuan ibu tentang perawatan anak yang kurang akibat usia menikah terlalu muda, tingkat pendidikan ibu, ras dan etnis, serta ekspektasi budaya. Sejumlah hal tersebut yang memengaruhi pola pengasuhan dan kualitas hidup anak dapat berakibat kematian dengan didahului oleh gizi buruk (Adetunji, 1995).

Demikian halnya dalam pola pengasuhan balita di Jember, pengetahuan yang didapatkan oleh ibu dari komunitas masyarakat dalam dan struktur sosialnya membuat ibu menjadikan pengetahuan tersebut sebagai suatu realitas yang subjektif. Apa yang dilihat sehari-hari dalam kehidupan ibu sejak masa kecil hingga mempunyai anak, keluarga dan budaya masyarakat turut berperan dalam perilaku ibu dalam memberikan pola asuh kepada balitanya. Termasuk wilayah geografis yang membedakan suatu wilayah itu sebagai sebuah perdesaan atau perkotaan juga membentuk pengetahuan yang adaptif terhadap kondisi wilayah dan keterbatasanketerbatasan yang ada atas akses dan pemenuhan akan kebutuhan.

Pengetahuan mengenai pola pengasuhan anak dipelajari oleh ibu dari kehidupannya sehari-hari dengan cara berinteraksi dengan sekitar. Masyarakat Desa Sucopangepok dan Kalisat Kabupaten Jember merupakan tipikal masyarakat Pendalungan yang sebagian besar menggunakan bahasa Madura sebagai bahasa sehari-harinya. Namun mereka tidak mengidentifikasikan diri mereka sebagai orang Madura melainkan sebagai orang Jember, lebih spesifik lagi sebagai orang Desa Sucopangepok dan orang Desa Kalisat.

Jember sebagai tempat pertemuan dua kebudayaan yaitu budaya Jawa dan Madura, melebur menjadi satu saling memberi pengaruh, menjadi budaya Pendalungan. Konsep Pendalungan adalah merupakan konsep yang muncul karena adanya percampuran budaya antar etnis Jawa dan etnis Madura di Wilayah Jawa Timur. Pendalungan berasal dari kata "dalung" yang berarti dulang besar terbuat dari logam. Secara simbolik memiliki arti yang menggambarkan suatu wilayah yang menampung beragam kelompok etnis dengan latar belakang budaya yang berbeda, yang melahirkan percampuran (hibridisasi) budaya (Yuswadi, 2008).

Penelitian J.M. Clendon 
menggambarkan bagaimana proses perempuan menjadi seorang ibu dan konstruksi apa yang dibangunnya. Dengan pendekatan sejarah sosial, ia mencermati buku The Well Child/ Tamariki Oral Health Book (the Plunket book) ${ }^{1}$ yang mencatat perkembangan dan pertumbuhan mulai dari sejak lahir hingga usia lima tahun. Ia mewawancarai 34 wanita dan seorang laki-laki. Dari wawancaranya, buku ini mampu mencermati pembentukan identas diri sebagai perempuan dan ibu dari generasi ke generasi, sekaligus menginformasikan tentang pengetahuan mereka, peran sosial dalam perawatan dan pengasuhan anak dari generasi ke generasi, serta hubungan sosial antara ibu dan bidan/perawat (nurse). Dalam pengasuhan dan perawatan anak (mothering), diketahui ada empat tahapan, yaitu: (1) proses menjadi ibu (becoming a mother), (2) merawat dan mengasuh anak (mothering a child), (3) merawat dan mengasuh orang dewasa (mothering an adult), (4) merawat dan membimbing seorang ibu (mothering a mother) (Clendon, 2009).

Tingkat pendidikan ibu di Jember membawa pengaruh pada pengetahuan ibu dalam mengasuh anak. Pendidikan ibu di perdesaan lebih rendah daripada di perkotaan Jember. Di desa tingkat pendidikan yang terbanyak adalah tidak tamat SD dan SMP, sedang di perkotaan tamat SMP dan SMA. Berdasar jumlah kasus gizi buruk dan stunting di wilayah perkotaan Jember lebih banyak, dikarenakan jumlah penduduknya lebih padat daripada di desa. Bukan berarti tingkat pengetahuan mereka berbeda, namun secara kebetulan penelitian di Jember ini menemukan kemiripan pemahaman atas apa yang dianggap paling bernilai dalam kehidupan mereka, yaitu kepemilikan atas modal ekonomi. Hal ini berdampak pada orientasi utama dalam kehidupan mereka adalah apa yang terlihat secara fisik nyata, seperti rumah tembok berkeramik, perhiasan, mebel dan lemari pajangan, yang dianggap sebagai investasi jangka panjang dan

Di Indonesia, dikenal dengan buku sehat yang diberikan pada ibu-ibu balita untuk penimbangan di posyandu. kebanggaan. Kondisi ini berbanding terbalik dengan kecukupan gizi anak balitanya.

Pola pengasuhan di lingkup keluarga juga berpengaruh terhadap tumbuh kembang balita. Lingkup keluarga adalah keluarga luas, di mana di perdesaan Jember umumnya setelah menikah mereka tinggal di lingkungan kerabat perempuan, sedangkan di perkotaan kecenderungan keluarga setelah menikah tinggal di lingkungan kerabat laki-laki. Dengan kondisi seperti ini anak bisa diasuh oleh beberapa orang di lingkup keluarganya itu. Lingkungan tinggal yang berbeda setelah menikah antara daerah perdesaan dan perkotaan ini ternyata membawa sebab tidak langsung pada pola pengasuhan balita. Pada ibu yang tinggal di keluarga perempuan (orang tua dan saudara sendiri), pengasuhan balita bisa dilakukan bersama-sama. Ada supporting system bagi ibu dari keluarganya dalam pola pengasuhan balita, sedangkan di wilayah perkotaan, ibu tinggal di keluarga suami, sehingga dalam berbagai situasi pengasuhan sering kali lebih diputuskan sendiri.

Selain itu, relasi suami dan istri terlihat tidak setara di Jember. Anak hanya urusan ibu semata, sehingga pola pengasuhan tertumpu pada seorang ibu. Bagi suami, anak merupakan penghibur dan pereda lelah saat mereka pulang kerja. Selain itu, anak juga menjadi alasan untuk giat bekerja, sedangkan ibu mengurus segala kebutuhan dalam seluruh rumah tangga. Keluarga luas hanya sesekali membantu, namun kewajiban sepenuhnya atas pengasuhan anak berada di tangan ibu. Di Jember baik di perdesaan maupun perkotaan, selain berperan mengurus anak, ibu juga mengurus hewan ternak sapi yang menjadi modal ekonomi keluarga. Ibu juga berperan dalam mengurus kebun dan/atau sawah, atau sebagai buruh penggarap kebun/sawah milik orang lain. Demikian halnya dengan ternak, ada yang punya sendiri, ada juga yang milik orang lain yang dititipkan dengan cara bagi hasil apabila peliharaan tersebut beranak.

Konstruksi sosial yang membentuk 
pemahaman ibu terkait pemberian ASI atau susu formula di Jember juga unik. Baik ibu yang bisa memberikan ASI kepada anaknya maupun ibu yang memiliki ASI sedikit, sama-sama menganggap bahwa susu formula dengan harga yang mahal masih lebih baik daripada ASI. Pandangan bayi masih lapar sehingga diperlukan tambahan susu formula juga terjadi di Jember. Pembahasan dikaitkan dengan temuan R.J. Wilma Hewat (1998) yang mencermati tentang proses pemberian ASI dan permasalahannya. Dengan menggunakan pendekatan kuantitatif dengan membandingkan dua kelompok ibu bermasalah dan tidak bermasalah dalam hal menyusui, ia menyimpulkan bahwa ada sejumlah faktor penyebab gangguan atau masalah dalam proses menyusui. Faktor psikologis ibu dari waktu hamil hingga melahirkan turut berpengaruh dalam hubungan emosional ketika menyusui. Faktor lain adalah berkaitan dengan pola kebutuhan asupan ASI dari bayi yang berbeda dengan segala perilaku menyusui ibu berakibat pada hubungan disharmoni antara ibu dan bayi. Selain itu, faktor ekonomi juga berpengaruh pada kemampuan menyusui ibu (Hewat, 1998).

Dari segi pengetahuan gizi balita, di perdesaan pengetahuan bahwa bayi atau balita mereka memiliki gizi bermasalah bisa diterima oleh ibu dan anggota keluarga yang lain. Namun, pengetahuan mengenai makanan sehat untuk bayinya tidak bisa masuk dalam koridor nilai yang dianggap berharga oleh mereka. Balita mereka makan apa yang mereka makan tanpa memperhitungkan asupan gizi yang masuk. Sementara itu, di wilayah perkotaan, pengetahuan bahwa bayi mereka mengalami gizi bermasalah mengalami penolakan (resistensi) akan keadaan sebenarnya balita. Balita dianggap sehat apabila makan dengan lahap, minta jajanan terus, dan beraktivitas main seperti balita yang lain. Namun, dalam penilaian bidan/Puskesmas, balita tersebut mengalami masalah gizi dengan ditandai oleh balita sering sakit dan pertumbuhan berat badan dan tinggi badan yang tidak sesuai dengan umurnya.

Selain asupan yang kurang, kejadian anak balita sering sakit juga menjadi penyebab terjadinya gangguan pertumbuhan. Sanitasi lingkungan yang buruk memengaruhi tumbuh kembang anak melalui peningkatan kerawanan anak terhadap penyakit infeksi. Anak yang sering sakit akibat rendahnya Perilaku Hidup Bersih dan Sehat (PHBS) dapat menyebabkan gangguan pertumbuhan kronis dan berdampak anak menjadi pendek. Temuan ini diperkuat dengan penelitian Purnamasari (2012) terhadap perawatan anak balita di daerah tempat pembuangan akhir menggunakan pendekatan teori konstruksi sosial. Pada penelitian tersebut mencari jawaban atas dua pertanyaan, yaitu makna PHBS dalam perawatan balita pada keluarga pemulung, dan bentuk perilaku perawatan kesehatan balita pada keluarga pemulung di Tempat Pembuangan Akhir (TPA) Benowo. Hasil dari penelitian ini menunjukkan bahwa keluarga pemulung dalam PHBS tidak terlalu mengkhawatirkan kondisi kesehatan anak balita mereka (Purnamasari, 2012).

\section{Penutup \\ Simpulan}

Kejadian gizi buruk pada balita sebagai suatu fenomena kesehatan bukan merupakan akibat yang berdiri sendiri dan bukan hanya urusan kesehatan saja. Dengan dipaparkannya pemetaan konstruksi sosial dari suatu masyarakat perdesaan dan perkotaan terkait erat dengan fenomena kejadian balita pendek dan kurang gizi, maka masalah yang sebenarnya menjadi penyebab mengapa terjadi gizi buruk balita dan balita pendek diketemukan. Bukan karena minimnya anggaran, kurangnya tenaga kesehatan, dan program-program terkait, namun lebih pada berbedanya komunikasi dan pemaknaan dari pihak penyelenggara pelayanan kesehatan (bidan desa, tenaga puskesmas dan dinas kesehatan) dengan yang ada di masyarakat. Konstruksi sosial yang dibangun juga berbeda, sehingga tidak ada titik 
temu untuk keberhasilan program peningkatan gizi balita.

Bukan masalah perilaku positif atau negatif terhadap pengetahuan kesehatan anak, ini semua terkait dengan harga diri dan identitas kelompok masyarakat yang terus berproses, dalam hal ini masyarakat Jember, khususnya masyarakat Desa Sucopangepok dan Desa Kalisat. Apabila penyelenggara pelayanan kesehatan (bidan desa, tenaga puskesmas dan dinas kesehatan) selalu memandang perilaku hanya dari segi "yang positif untuk kesehatan harus diteruskan dan yang negatif harus dihentikan", tanpa memandang karakteristik dari masyarakat penganut nilai budaya tertentu berinteraksi dengan sekitarnya dan kenyataan hidup mereka sehari-hari, maka permasalahan gizi buruk, balita pendek (stunting) dan permasalahan kesehatan pada umumnya, tidak akan pernah bisa diselesaikan meskipun banyak program dan anggaran yang digelontorkan untuk mengatasi masalah kesehatan tersebut. Masyarakat bukan hanya semata sebagai suatu gejala penyakit yang harus diobati penyebabnya lalu selesai, tetapi masyarakat adalah produk dari pengetahuan yang berproses, berinteraksi dengan sesamanya, dan bernegosiasi untuk menentukan objektivitas dalam maknamakna yang subjektif (yang berbeda-beda pemahaman dari individu-individu anggota masyarakat) sehingga memunculkan suatu kesadaran bersama.

\section{Saran}

Pemetaan konstruksi sosial masyarakat terkait fenomena balita pendek (stunting) telah diketahui yaitu anak pendek dianggap bukan sebagai masalah gizi balita, maka bagi pengampu kepentingan terkait program perbaikan gizi balita dan lintas sektor diharapkan program penyuluhan bisa lebih tepat guna dengan menyasar pada konsep yang dianggap berharga oleh suatu masyarakat. Apa yang dianggap berharga dalam suatu komunitas akan menjadi sangat penting dalam pendekatan terhadap masyarakat itu untuk mengubah pengetahuan secara internal budayanya.

Yang perlu dibangun adalah membentuk konstruksi masyarakat yang berubah terkait hubungan intersubjek (antarmasyarakat dan penyelenggara pelayanan kesehatan masyarakat) dalam membentuk pengetahuan baru seperti bahwa dengan memberikan pemahaman terkait tumbuh kembang anak berdasar pengetahuan kesehatan adalah investasi yang baik pada anak sesuai nilai yang berkembang di masyarakat, termasuk bahwa anak pendek (stunting) juga sebagai suatu masalah kesehatan di masa depan anak. Tenaga kesehatan juga harus membangun kedekatan dan trust dengan masyarakat, yang dalam hal ini sudah mulai berproses menuju kesana. Perlu pula menegosiasikan pengetahuan baru, di mana kesehatan anak merupakan konstruksi mereka dalam memandang yang dianggap bernilai dalam investasi mereka di masa mendatang. Bukan sekedar pengetahuan dari luar yang akan memberi stigma komunitas mereka, bahwa pengetahuan ini sudah ada dalam struktur bangunan pengetahuan mereka sendiri. Pendekatan humanis yang mengedepankan empati kepada masyarakat itu sendiri lebih dibutuhkan untuk mengubah perilaku dan pengetahuan masyarakat akan hidup bersih dan sehat. Pengetahuan medis modern yang diakui sebagai pengetahuan lokal yang terkonstruksi dalam pengetahuan masyarakatnya sendiri, akan lebih mudah diterima daripada harus mempertentangkan pengetahuan medis modern yang dianggap positif terhadap kesehatan dengan pengetahuan lokal masyarakat yang dianggap negatif terhadap perbaikan kesehatan, gizi balita pada khususnya.

\section{UCAPAN TERIMA KASIH}

Ucapan terima kasih kami sampaikan kepada Kepala Seksi Informasi dan Penelitian Pengembangan Dinas Kesehatan Kabupaten Jember, Kepala Seksi Gizi Dinas Kesehatan Kabupaten Jember, Kepala Puskesmas 
Kecamatan Jelbuk dan Kecamatan Kalisat beserta seluruh jajarannya, Warga Masyarakat Desa Sucopangepok dan Desa Kalisat dan Tim peneliti dengan kerja kerasnya sehingga penelitian ini bisa berjalan dengan lancar. Ucapan terima kasih sebesar-besarnya kami sampaikan kepada rekan dan kawan kami almarhum Dr. Moch. Setyo Pramono, S.Si., M.Si., atas jasa beliau penelitian ini bisa terlaksana.

\section{DAFTAR PUSTAKA}

\section{Jurnal}

Adetunji, Jacob Ayo. (1995). "Infant Mortality and Mother's Education in Ondo State, Nigeria." Social Science Medicine. Vol. 40. No. 2.

Burchinal, Margaret R., dan Lauren Nelson. (2000). "Family Selection and Child Care Experiences: Implications for Studies of Child Outcomes." Early Childhood Research Quarterly, Vol. 15, No. 3.

Menon, Purnima; Ruel, Marie T.; Morris, Saul Sutkover. (2000). Socioeconomic "Differentials in Child Stunting Are Consistently Larger in Urban Than Rural Areas: Analysis of 10 DHS Data Sets." Food and Nutrition Bulletin, 21(3): 282289.

Sudiman, H. (2008). "Stunting atau Pendek : Awal Perubahan Patologis atau Adaptasi karena Perubahan Sosial Ekonomi yang Berkepanjangan?." Media Litbang Kesehatan; 18(1): 33-43.

\section{Buku}

Butt, Leslie. (1998). The Social and Political Life of Infants among the Baliem Valley Dani, Irian Jaya. Dissertation. Montreal: McGill University.

Cockerham, William C. (1978). Medical Sociology. Englewood Cliffs, New Jersey: Prentice-Hall,Inc.
Craib, Ian. (1986). Teori-teori Sosial Modern. Dari Parsons sampai Habermas. Terjemahan oleh Paul S. Baut dan T. Effendi. Jakarta: Rajawali.

Danandjaja, James. (1980). Kebudayaan Petani Desa Trunyan di Bali. Jakarta: Pustaka Jaya.

Foster, G.M., dan B.G. Anderson. (1986). Antropologi Kesehatan. Jakarta: Unversitas Indonesia Press.

Geertz, Hildred. (1985). Keluarga Jawa. Jakarta: Grafiti Press.

Habsjah, Atashendartini. (1995). "Sekelumit Kehidupan Kaum Perempuan Beserta Anaknya di Beberapa RT Kumuh" Jakarta dalam T.O. Ihromi. Kajian Wanita dalam Pembangunan. Jakarta: YOI.

Koentjaraningrat. (1979). Pengantar Ilmu Antropologi. Jakarta : Rineka Cipta.

Noack, H. (1987). Concepts of health and health promotion. In: Abelin, T. et al., ed. Measurement in health promotion and protection. Copenhagen, WHO Regional Office for Europe (WHO Regional Publications, European Series, No. 22).

Peter L. Berger \& Luckman, Thomas. (1990). Tafsir Sosial atas Kenyataan. Jakarta: LP3S.

Ritzer, George. (1988). Contemporary Sociological Theory. New York: Alfred A. Knopf.

Uyanga, Joseph T. (1980). A Geography of Rural Development in Nigeria. University Press of America.

Yuswadi H, (2008). "Budaya Pendalungan: Bentuk Multikulturalitas dan Hibridisasi Budaya Antar Etnik" dalam Ayu Sutarto dan Setya Yuwana Sudikan, ed., Pemetaan Kebudayaan di Provinsi Jawa Timur Sebuah Upaya Pencarian Nilai-Nilai Positif ( $\mathrm{p}$. 53-69), Biro Mental Spiritual Pemerintah Provinsi Jawa Timur Bekerja sama dengan Kompyawisda Jawa Timur, Jember.

\section{Dokumen}

Kementerian Kesehatan RI. (2010). Keputusan Menteri Kesehatan Nomor 1995/MENKES/ SK/XII/2010 tanggal 30 Desember 2010 tentang Standar Antropometri Penilaian Status Gizi Anak, Kementerian Kesehatan RI. Jakarta. 


\section{Laporan}

Departemen Kesehatan RI: Badan Penelitian dan Pengembangan Kesehatan. (2008). Laporan Nasional Riset Kesehatan Dasar 2007, Badan Penelitian dan Pengembangan Kesehatan Departemen Kesehatan RI. Jakarta.

Dinas Kesehatan Propinsi Jawa Timur. (2011). Profil Kesehatan Propinsi Jawa Timur. Surabaya.

Kementerian Kesehatan RI: Badan Penelitian dan Pengembangan Kesehatan. (2010). Riset Kesehatan Dasar 2010, Badan Penelitian dan Pengembangan Kesehatan Kementerian Kesehatan RI. Jakarta.

Kementerian Kesehatan RI: Badan Penelitian dan Pengembangan Kesehatan. (2013). Riset Kesehatan Dasar 2013, Badan Penelitian dan Pengembangan Kesehatan Kementerian Kesehatan RI. Jakarta.

Mahirawati, et al. (2007). Konsumsi Energi Dan Protein Anak Umur 7 - 23 Bulan di Perkotaan dan Pedesaan di Indonesia. Laporan Penelitian Puslitbang Gizi Dan Makanan 2007 Badan Litbang Kesehatan, Kemkes. RI. Bogor.

Puskesmas Kecamatan Jelbug. (2013). Profil Puskesmas Kecamatan Jelbug 2013. Jember.

Puskesmas Kecamatan Kalisat. 2013. Profil Puskesmas Kecamatan Kalisat 2013. Jember.

\section{Skripsi/Tesis/Disertasi}

Clendon, Jillian Margaret (2009). Motherhood and the "Plunket Book": A Social History. Dissertation. Auckland, NZ: Massey University.
Hewat, Roberta Jean Wilma. (1998). "MotherInfant Interaction During Breastfeeding. A Comparison between Problematic and Nonproblematic Breastfeeders." Dissertation. Edmonton, Alberta: Alberta University.

Purnamasari, Y. (2012). "Makna PHBS dalam Perawatan Balita pada Keluarga Pemulung (Studi Tentang Makna Perilaku Hidup Bersih Sehat dalam perawatan kesehatan Balita pada keluarga pemulung TPA Benowo Surabaya)," Skripsi. Surabaya: Universitas Airlangga.

Wahdah, Siti. (2012). "Faktor Risiko Kejadian Stunting Pada Anak Umur 6-36 Bulan di Wilayah Pedalaman Kecamatan Silat Hulu Kabupaten Kapuas Hulu Provinsi Kalimantan Barat." Tesis. Yogyakarta : Program Pasca Sarjana Fakultas Kedokteran Universitas Gadjah Mada.

\section{Surat Kabar}

42 Persen Anak Jatim Terancam Pendek. Jawa Pos 20 Januari 2012. Surabaya.

\section{Lain-lain}

Hadiat. (2013). "Gerakan Nasional Percepatan Perbaikan Gizi (Peraturan Presiden RI No. 42 Tahun 2013)", Paparan Direktur Kesehatan dan Gizi Masyarakat Kementerian PPN/Bappenas Disampaikan Pada Talkshow Gerakan Nasional 1000 HPK Jakarta, 18-20 Oktober 2013. 